\title{
Chemical and Hydro-Physical Peat Characteristics under Agricultural Peat Land Management in Central Kalimantan, Indonesia
}

\author{
Andi Gustiani Salim, Budi Hadi Narendra*, I Wayan Susi Dharmawan, Pratiwi \\ Forest Research and Development Center, Ministry of Environment and Forestry, \\ Jln. Gunung Batu no.5 Bogor 16610, Indonesia
}

Received: 27 January 2021

Accepted: 17 March 2021

\begin{abstract}
The utilization of peatlands as agricultural areas that does not pay attention to the sustainability aspects often contributes to climate change and the decline in the peat ecosystem function. For better peatland management and to prevent more severe environmental losses, knowledge of the impacts on chemical and hydro-physical peat characteristics in a specific area is required. This study was aimed to assess the chemical and hydro-physical characteristics of the peat utilized as agricultural land. The study was conducted by field measurements and peat sample analysis in the laboratory. The results indicated that peat managed as agricultural land is categorized as deep inland peat with more than $3 \mathrm{~m}$ thickness and dominated by sapric type in the surface layer. Intensive agricultural management significantly changes some peat's chemical characteristics by increasing the $\mathrm{pH}$, phosphor, potassium, calcium, and magnesium contents. Otherwise, the peat management has lowered the hydrological function characterized by increasing water level depth, bulk density, reducing the water content and hydraulic conductivity. Hydrological peat functions on agricultural peatland should be restored by applying appropriate canal blocking. Paludiculture systems should be considered as promising agricultural land management that combines adaptive crops and suitable tree species with high economic value for the community.
\end{abstract}

Keywords: peatland management, chemical, hydro-physical, canal blocking, paludiculture

\section{Introduction}

Peatlands are wetland ecosystems characterized by the accumulation of organic material that lasts for a long time [1]. Peat formation in a tropical forest ecosystem is generally located in a relatively flat

*e-mail: narendra17511@gmail.com topography with high rainfall. The accumulation of organic matter is due to the high litter production and the low decomposition rate due to waterlogging and lack of oxygen $[2,3]$. Indonesia's tropical peat covers about 15 million hectares, spread across three major islands, namely Sumatera, Kalimantan, and Papua [4]. The peat's unique nature, which can store water up to $90 \%$ of its weight, causes a very large role as a hydrological buffer for the surrounding area [5]. Damage to peatland ecosystems due to peat drainage has significant impact 
on the local and the surrounding environment. The peat characteristics' changes will lead to high fire vulnerability, worsening land subsidence, flood [6], and germplasm loss.

Conserving forested peatland as a habitat for hundreds of forest plant species and their faunas is an appropriate policy. Utilization of peatlands for crops, estate plantations, or forest plantations, regardless of the peat sustainability, is classified as very vulnerable, especially if taking place on the thick peat. The essential peat preservation requirement is permanent waterlogging [7]. Meanwhile, land-use change in the tropical peat swamp forest generally requires an effort to adjust the water level by making drainage channels [8]. Recently in Indonesia, the idea of utilizing degraded peatlands on a large scale as agricultural land has resurfaced. Peatland that is not managed sustainably will negatively impact the environment, such as the increase in greenhouse gas emissions, and further reduce the characteristics and roles of the tropical peat [9].

It has been reported that changes in water behavior due to peat drainage and forest cover conversion result in biogeochemical processes through peat decomposition [5]. The degree of change in the physical and chemical properties of peat depends on the level of disturbance in the form of drainage level, the intensity of forest conversion, or the land management practices [10]. Several studies have identified changes in peat properties due to fire, drainage canals, or forest conversion to agricultural land, oil palm plantations, rubber plantations, or short-rotation woody plantations [10-15]. However, there is a lack of knowledge regarding the effect of differences in agricultural land management on changes in peat properties. The sitespecific degree of peat degradation needs to be assessed as the basis for better peatland management so that further degradation can be minimized [16]. Therefore, this research's objective was to assess the chemical and hydro-physical characteristics of the peat in different agricultural land management. This paper tries to narrow the gap between research communities working on the peat properties of degraded peatlands. Also, this research result will contribute to better peatland management in Indonesia.

\section{Materials and Methods}

\section{Study Area}

The fieldwork was carried out in agricultural areas of Kalampangan village and a peat swamp forest area in Tumbang Nusa village. As shown in Fig. 1, the site is located between $114^{\circ} 0^{\prime} 52^{\prime \prime} \mathrm{E}-114^{\circ} 5^{\prime} 17^{\prime} \mathrm{E}$ and $2^{\circ} 17^{\prime} 11^{\prime} \mathrm{S}-2^{\circ} 21^{\prime} 31^{\prime \prime} \mathrm{S}$, around $20 \mathrm{~km}$ from Palangkaraya, the capital city of Central Kalimantan Province.

The agricultural peatlands were opened in 1979 as part of transmigration programs of 500 households.

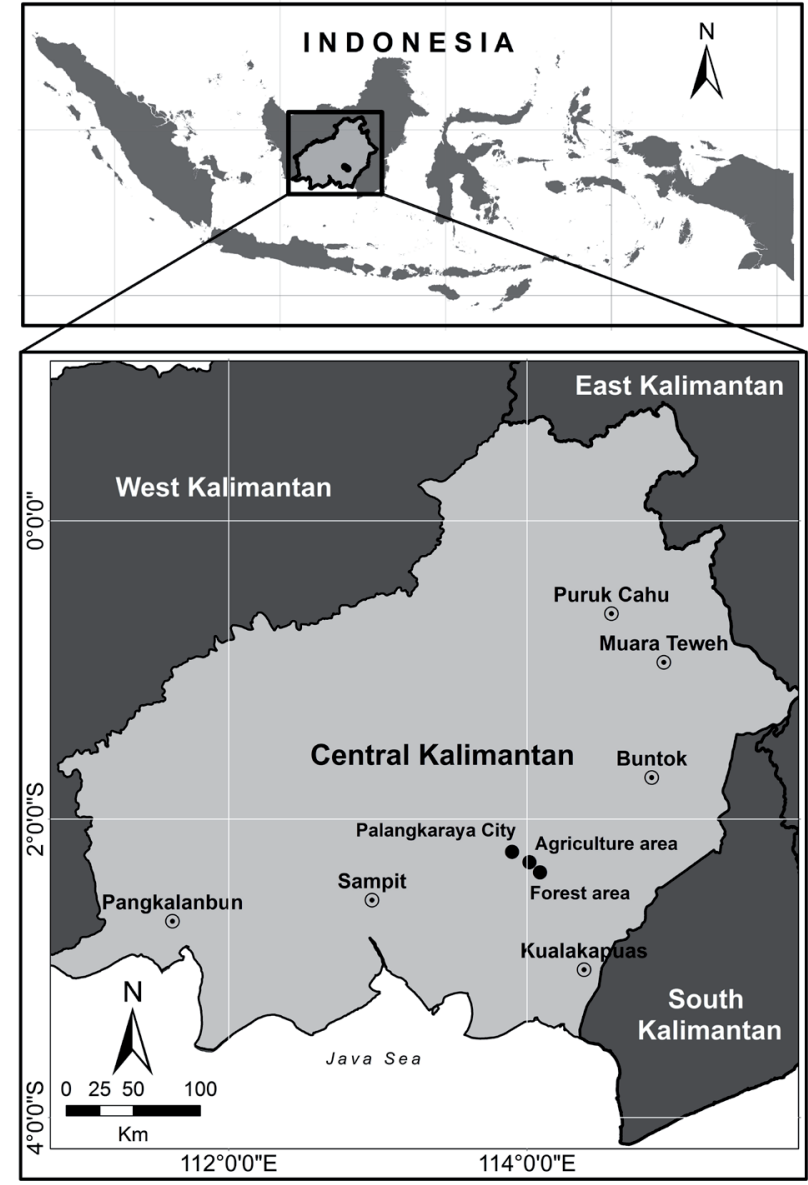

Fig. 1. The study site in Central Kalimantan.

Although some farmers have now succeeded in developing vegetable crops, the first ten years were the most challenging period for migrants to process the land. Some of them have experience in agriculture in mineral soil that is much different from the peatland. In the beginning, they tried to grow rice but always fail and begin to switch to vegetable crops or horticulture and get success up to date.

\section{Methods}

This research was carried out by field explorative survey on three land management types, namely the intensive and non-intensive agricultural peatland and peat swamp forest area as a comparison area. The materials and tools used in this study were soil sample bags, labels, peat core samplers, Eijkelkamp peat auger, a Munsell Soil Color Chart, a digital scale, a DC suction pump, and polyvinyl chloride (PVC) pipes.

Peat observed characteristics include the thickness, water level depth, maturity, color, chemical, and hydrophysical. The chemical elements were obtained through peat samples taken using the peat auger, and the analysis was done in the Soil Research Center Laboratory. Sampling was conducted purposively for three areas in each land management type. Chemical analyses 
were performed on soil $\mathrm{pH}$ using a glass electrode in 1:2.5 suspension of soil and distilled water [17]; total organic carbon (TOC) and ash content quantified using loss on ignition method [14, 18]; total nitrogen content determined using the Kjeldahl method [19]; available phosphorus $(\mathrm{P})$, available potassium $(\mathrm{K})$, exchangeable cations $(\mathrm{Ca}, \mathrm{Mg}, \mathrm{Na}, \mathrm{K})$, and cation exchange capacity (CEC) were determined following the standard method of soil analysis [20].

Peat hydro-physical characteristics were determined based on field measurement of hydraulic conductivity. The measurements were carried out using a slug test. This procedure used a piezometer made of PVC pipe [21]. Physical peat characteristics were assessed through direct field measurement and peat laboratory analysis. The samples were collected using core samplers [22]. Dry weight and water content were derived using the gravimetric method by oven-dried the samples at $105^{\circ} \mathrm{C}$ for 48 hours [5]. The measured constant weight indicates the weight of dry peat. The bulk density was determined based on the dry peat weight and the sample volume [18]. The supporting data were also collected in historical land management, land degradation causes, and actions carried out in each land management pattern ranging from land preparation, crop species, maintenance, and plant productivity.

Peat characteristics were analyzed statistically using SAS 9.0 software to determine the significant effect of the different peat management on the observed variables. Duncan's Multiple Range Test (DMRT) will be conducted if the results have a significant difference. The possible relationship between variables was assessed using the CORR procedure produces Pearson correlation coefficients. The resulting correlation coefficients ranged from negative one $(-1)$ to positive one $(+1)$. A positive coefficient means that if the values in one variable are increasing, the value in the other variable increase as well. The opposite happens if the coefficient is negative, and if the coefficient is close to zero it indicates there is no or weak correlation $[23,24]$.

\section{Results}

\section{General Characteristics}

Kalampangan and Tumbang Nusa peatland are located between two rivers, namely Kahayan and Sebangau River. The land has a plane flat alluvial form composed of alluvial materials such as clay, organic matter, and sometimes there is sand coming from the river. Peat thickness can reach up to $12 \mathrm{~m}$, and the layer below the peat is dominated by quartz sand. The peat is including oligotrophic ombrogen type characterized by acid up to very acid soil reaction, high CEC, and low available nutrient for the plant. This peat soil is classified as tropohemist with parent material is dominated by vegetation remnants in the form of wood.
The peat content in Central Kalimantan is dominated by lignin up to $93 \%$, cellulose less than $10 \%$, and hemicellulose and protein are not found [25]. General peatland conditions in the observed areas of agriculture and forest are presented in Table 1.

The study area's hydrological conditions are heavily influenced by the main canals that stretch between the two main rivers. Farmers have made micro drainage canals around the agricultural plots equipped with the drain plug for the water level maintenance and collecting/depositing soil particles transported by runoff. As the water level was set with canals, the deepest water table was found on the intensive agricultural land with $38 \mathrm{~cm}$ depth. The lowest was in the forest with an average of $8 \mathrm{~cm}$. The deeper position of the water from the peat surface, the peat is more exposed the oxygen so the decomposition of organic matter accelerates and releases $\mathrm{CO}_{2}$ [26].

Peat sample analysis for each $50 \mathrm{~cm}$ layer depth shows color variations range from $2.5 \mathrm{Y} 2 / 1$ (black) to 10 YR 5/6 (yellowish-brown). On agricultural lands, darker colors are generally found in the surface layer. In contrast, in the forest, the dark colors can be found variously in the top, middle, or bottom layer.

Based on the maturity level, peat is classified into fibric, hemic, or sapric, ranging from low to high. In the forest, there is still found fibric peat (raw peat) in the first $50 \mathrm{~cm}$ layer, and the rest is dominated by hemic type. In the agriculture area, both the first and the second $50 \mathrm{~cm}$ layers are dominated by sapric type, and the rest is dominated by hemic. The peat maturity process's speed increases due to the cultivated peat having faster oxidation and decomposition [27].

Cultivated crop species include spinach, kale, mustard greens, salad, cucumbers, string beans, corn, peppers, tomatoes, red onion, pineapple, guava, and starfruit. Agricultural land preparation was done by collecting scraps of wood or stumps left in the land. The timber was collected together with the remains of plants and weeds subsequently burned to ash as the input gain before planting. Ash needs to be different each time for each planting crop, such as corn need $16 \mathrm{t} \mathrm{ha}^{-1}$, celery $117 \mathrm{t} \mathrm{ha}^{-1}$, spinach $93 \mathrm{t} \mathrm{ha}^{-1}$, mustard $18 \mathrm{t} \mathrm{ha}^{-1}$, and kale $43 \mathrm{t} \mathrm{ha}^{-1}$ [28]. In addition to ash's input, they usually add lime, manure, mineral soil, or chemical fertilizers such as urea, Triple Super Phosphate (TSP), and Potassium Chloride $(\mathrm{KCl})$. Within a year, the lime can be added as much as $0.5 \mathrm{t} \mathrm{ha}^{-1}$, while cow dung manure was added up to $2.5 \mathrm{t} \mathrm{ha}^{-1}$. Urea was applied directly to the plant at a dose of up to 200 grams per plant depending on the crop species, while $\mathrm{P}$ and $\mathrm{K}$ fertilizer was applied by spraying on the leaves. Processing was done by hoeing up $30 \mathrm{~cm}$ depth soil layer. Harvesting is usually done on every plant crop plot measuring $20 \times 30 \mathrm{~m}$ or done on each lane/raised beds where the plot consists of 30 lines of planting. Harvested commodity prices depend on the market price as determined by the abundance of similar products on the market. 


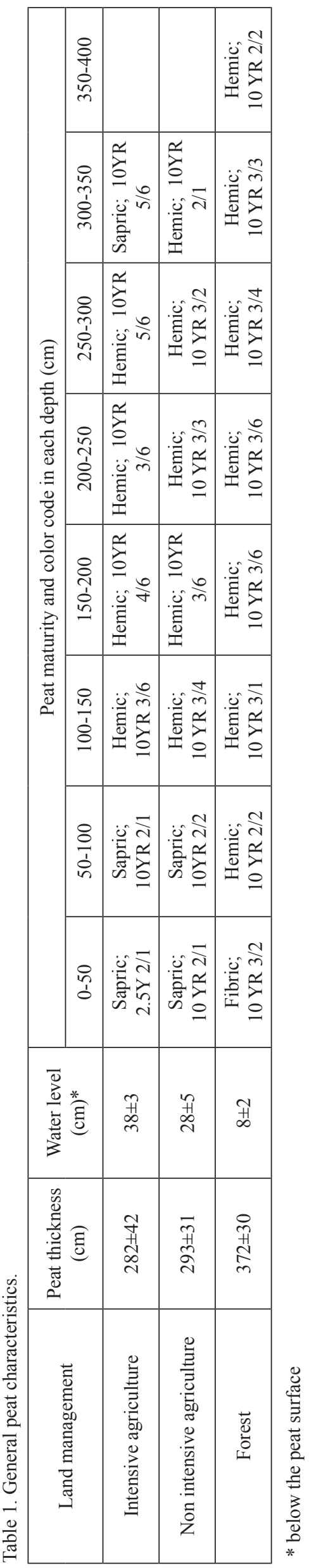

\section{Chemical Characteristics}

The chemical characteristics of peat are influenced by the composition of the constituent materials, the environmental conditions in which it is located, and the degree of decomposition. The peat decomposition process will change the peat structure and the chemical composition of the peat [29]. The peat chemical characteristics presented in Table 2 showed that the peat acidity in both the agriculture or forested sites was very acid $(<4.5)$. Oxidation and the additional materials used as input in the agricultural land were only able to increase the peat's $\mathrm{pH}$ slightly. At the intensive agriculture location, the mean $\mathrm{pH}$ was 3.6, while the $\mathrm{pH}$ in the surface layer measured at 3.7. This $\mathrm{pH}$ value is relevant to the $\mathrm{pH}$ results studied by [25] that showed the $\mathrm{pH}$ of Central Kalimantan peat was around 3.41 to 3.97 . In a tropical peat swamp forest, the $\mathrm{pH}$ is closely related to the presence of phenolic acids mostly leached from leaf litter and dead trees [30].

The peat in the three research locations, like peat in general, has a high organic carbon content. Both organic $\mathrm{C}$ content under agricultural management show significantly higher $\mathrm{C}$ content than in the forested peat. On the other hand, higher total nitrogen content was found in the forested peatland although the difference was not significant. The trend in $\mathrm{C}$ and $\mathrm{N}$ peat content was similar to the research results of [11] which showed that the $\mathrm{C}$ content of peat was found to be significantly higher in degraded peatland caused by intensive drainage and fire, than in peat swamp forest. On the other hand, the highest $\mathrm{N}$ content was found in the peat swamp forest.

Based on the results of the correlation analysis in Table 3, the contents of $\mathrm{C}$ and $\mathrm{N}$ have a strong negative relation. The $\mathrm{C} / \mathrm{N}$ ratio in all observation areas was also high, with the highest mean value reach 41.7. This value is very high compared to the $\mathrm{C} / \mathrm{N}$ ratio of mineral soils, which means the overall value is only 10.9 [31]. This condition shows that N, which is one of the structures that make up organic matter, is available in low quantities to become a limiting factor for plant growth [32].

The $\mathrm{P}$ and $\mathrm{K}$ elements have the highest concentrations found in the intensive agricultural land, and the lowest is in forested peat. The high levels of these nutrients that are often found in agricultural peatlands are due to intensive fertilization which is sometimes accompanied by liming [33]. Base on the correlation analysis, the amount of $\mathrm{P}$ and $\mathrm{K}$ element are highly correlated to the exchangeable $\mathrm{Ca}$ and $\mathrm{Mg}$. Peat degradation also increases the mineralization of the elements N, P, K, and the amount of which depends on the actual concentration [34].

The highest amount of exchangeable $\mathrm{Ca}, \mathrm{Mg}$, and $\mathrm{K}$ were observed in intensive agriculture, while the lowest was in the forested peat. This exchangeable increase affects increasing the base saturation value, although 
Table 2. Chemical peat characteristics.

\begin{tabular}{|c|c|c|c|}
\hline \multirow{2}{*}{ Variable of observations } & \multicolumn{3}{|c|}{ Land management } \\
\hline & Intensive agricultural & Non-intensive agricultural & Forest \\
\hline $\mathrm{pH} \mathrm{H}_{2} \mathrm{O}$ & $3.6 \pm 0.08 \mathrm{a}$ & $3.5 \pm 0.15 \mathrm{a}$ & $3.5 \pm 0.11 \mathrm{a}$ \\
\hline Organic C $(\%)$ & $51.6 \pm 3.3 \mathrm{a}$ & $51.6 \pm 4.4 \mathrm{a}$ & $48.7 \pm 4.8 \mathrm{~b}$ \\
\hline Total N (\%) & $0.92 \pm 0.08 \mathrm{a}$ & $0.86 \pm 0.07 \mathrm{a}$ & $0.99 \pm 0.12 \mathrm{a}$ \\
\hline $\mathrm{C} / \mathrm{N}$ & $41.7 \pm 2.0 \mathrm{a}$ & $31.9 \pm 3.7 \mathrm{a}$ & $36.6 \pm 6.2 \mathrm{a}$ \\
\hline Available P (ppm) & $66.72 \pm 8.8 \mathrm{a}$ & $29.97 \pm 12.6 \mathrm{~b}$ & $14.38 \pm 6.0 \mathrm{~b}$ \\
\hline Available K (ppm) & $240.8 \pm 33 \mathrm{a}$ & $117.2 \mathrm{a} \pm 36 \mathrm{~b}$ & $69.8 \pm 11 \mathrm{~b}$ \\
\hline Exchangeable $\mathrm{Ca}\left(\mathrm{cmol}^{(+)} \mathrm{kg}^{-1}\right)$ & $2.8 \pm 0.2 \mathrm{a}$ & $2.0 \pm 0.14 \mathrm{ab}$ & $1.4 \pm 0.24 \mathrm{~b}$ \\
\hline Exchangeable $\mathrm{Mg}\left(\mathrm{cmol}^{(+)} \mathrm{kg}^{-1}\right)$ & $1.75 \pm 0.21 \mathrm{a}$ & $1.62 \pm 0.30 \mathrm{a}$ & $0.86 \pm 0.14 \mathrm{a}$ \\
\hline Exchangeable $\mathrm{K}\left(\mathrm{cmol}^{(+)} \mathrm{kg}^{-1}\right)$ & $0.48 \pm 0.10 \mathrm{a}$ & $0.23 \pm 0.08 \mathrm{ab}$ & $0.14 \pm 0.05 \mathrm{~b}$ \\
\hline Exchangeable $\mathrm{Na}\left(\mathrm{cmol}^{(+)} \mathrm{kg}^{-1}\right)$ & $0.52 \pm 0.12 \mathrm{a}$ & $0.84 \pm 0.12 \mathrm{a}$ & $0.76 \pm 0.17 \mathrm{a}$ \\
\hline $\operatorname{CEC}\left(\mathrm{cmol}^{(+)} \mathrm{kg}^{-1}\right)$ & $105.8 \pm 4.6 \mathrm{a}$ & $114.5 \pm 6.3 \mathrm{a}$ & $68.2 \pm 2.7 \mathrm{~b}$ \\
\hline Base saturation $(\%)$ & $5.17 \pm 0.55 \mathrm{a}$ & $4.00 \pm 0.82 \mathrm{a}$ & $4.75 \pm 0.55 \mathrm{a}$ \\
\hline Ash (\%) & $0.9 \pm 0.10 \mathrm{~b}$ & $0.8 \pm 0.09 \mathrm{~b}$ & $1.7 \pm 0.53 \mathrm{a}$ \\
\hline
\end{tabular}

Note: the values in the same row followed by the same letters indicate no significant difference $(\mathrm{p} \leq 0.05)$

not significantly. This exchangeable increase, especially in $\mathrm{Ca}$ and $\mathrm{Mg}$, was possible due to the application of dolomite by farmers. This has also been proven by [35] where dolomite treatment significantly increases base saturation due to the contribution of exchangeable cations.

In general, peat has a high $\mathrm{CEC}$ value due to the peat material that is dominated by timber decomposition. This material has a high lignin content causing produce phenolic acid during the decomposition process [25]. Changes in CEC values often occur due to changes in peatland use. Changes that tend to increase base saturation and $\mathrm{pH}$ will also have implications for increasing CEC [36].

\section{Physical and Hydrological Characteristics}

Analysis of physical characteristics showed several variable values on agricultural peatland showed significantly different from the control (forested peat). Processing of peatland for farming purposes has significantly increased dry weight, bulk density, and lowered water content. Table 4 shows peat drying up on agricultural lands through drainage channels, and the addition of ameliorant has increased the peat bulk density.

Increasing peat bulk density impacts peat's ability to absorb and hold the water (water holding capacity). Water content values indicate that on the agricultural site, the peat can absorb up to eight times of the dry peat's weight, while for the forested peat, it capable up to nine times. This condition is in line with the research results on peat characteristics in various uses in South
Sumatra Province. Peatlands covered by high-density forest or water bodies are areas that have the highest level of wetness compared to other land uses such as agriculture, plantations, shrubs, or grass [37].

Statistical analysis showed that peat management in intensive agriculture significantly increases the bulk density variable: the denser a peat material, the more difficult it is to penetrate water or roots. Correlation analysis stated in Table 5 indicates that peat bulk density has a high correlation with the other variables. The positive correlation was identified with the dry peat weight, and the negative values were found in the correlation with water content and hydraulic conductivity.

Higher peat bulk density indicates a high amount of total peat material per volume, providing better physical support to the plants. Good water content in the soil will play an essential role in plant growth. However, in certain plant species, too much water will restrict air movement in the soil, hinder plant roots from acquiring $\mathrm{O}_{2}$, and interfere with plant growth. In addition to increased bulk density, on-farm activities can also result in peat compaction [22].

The decline of peat hydrological function is also indicated by the decrease of hydraulic conductivity measured in the field. The average of measurement results presented in Table 4 shows that water's ability to move through the peatland decreases up to 280 times in the peat being converted into agricultural land. Disturbance to the peat, especially on the peat surface, affects hydro-physical properties. The higher level of peat decomposition, indicated by the increase in bulk density, will inhibit the movement of water by 
Table 3. Correlation analysis between peat chemical variables.

\begin{tabular}{|c|c|c|c|c|c|c|c|c|c|c|c|c|}
\hline $\begin{array}{c}\text { Vari- } \\
\text { able }\end{array}$ & $\mathrm{C}$ & $\mathrm{N}$ & $\mathrm{C} / \mathrm{N}$ & $\mathrm{P}$ & $\mathrm{K}$ & $\mathrm{E} . \mathrm{Ca}$ & E.Mg & E.K & E.Na & CEC & BS & Ash \\
\hline $\mathrm{pH}$ & 0.50 & -0.04 & 0.88 & 0.96 & 0.96 & 0.90 & 0.61 & 0.97 & -0.97 & 0.34 & 0.77 & -0.41 \\
\hline $\mathrm{C}$ & & -0.89 & 0.02 & 0.73 & 0.71 & 0.82 & 0.99 & 0.70 & -0.28 & 0.98 & -0.16 & -0.99 \\
\hline $\mathrm{N}$ & & & 0.44 & -0.33 & -0.31 & -0.47 & -0.82 & -0.30 & -0.20 & -0.95 & 0.60 & 0.93 \\
\hline $\mathrm{C} / \mathrm{N}$ & & & & 0.70 & 0.72 & 0.59 & 0.16 & 0.73 & -0.97 & -0.15 & 0.98 & 0.08 \\
\hline $\mathrm{P}$ & & & & & 1.00 & 0.99 & 0.82 & 1.00 & -0.86 & 0.60 & 0.56 & -0.66 \\
\hline $\mathrm{K}$ & & & & & & 0.99 & 0.80 & 1.00 & -0.87 & 0.58 & 0.58 & -0.64 \\
\hline $\mathrm{E} . \mathrm{Ca}$ & & & & & & & 0.89 & 0.98 & -0.78 & 0.71 & 0.43 & -0.76 \\
\hline $\mathrm{E} . \mathrm{Mg}$ & & & & & & & & 0.79 & -0.40 & 0.95 & -0.03 & -0.97 \\
\hline $\mathrm{E} . \mathrm{K}$ & & & & & & & & & -0.88 & 0.57 & 0.59 & -0.63 \\
\hline $\mathrm{E} . \mathrm{Na}$ & & & & & & & & & & -0.10 & -0.90 & 0.18 \\
\hline $\mathrm{CEC}$ & & & & & & & & & & & -0.33 & -1.00 \\
\hline $\mathrm{BS}$ & & & & & & & & & & & & 0.26 \\
\hline Ash & & & & & & & & & & & \\
\hline
\end{tabular}

Remarks: E.Ca = Exchangeable Ca; E.Mg = Exchangeable Mg; E.K = Exchangeable K; E.Na = Exchangeable Na;

$\mathrm{BS}=$ base saturation

Table 4. Hydro-physical peat characteristics.

\begin{tabular}{|c|c|c|c|}
\hline \multirow{2}{*}{ Variable of observation } & \multicolumn{3}{|c|}{ Land management } \\
\cline { 2 - 4 } & Intensive agricultural & Non-intensive agricultural & Forest \\
\hline Bulk Density (g/cc) & $0.12 \pm 0.02 \mathrm{a}$ & $0.13 \pm 0.02 \mathrm{a}$ & $8.09 \pm 0.01 \mathrm{~b}$ \\
\hline Water content (\%) & $87.4 \pm 2.5 \mathrm{~b}$ & $86.8 \pm 1.7 \mathrm{~b}$ & $9.3 \pm 1.1 \mathrm{~b}$ \\
\hline Dry peat weight (gr) & $11.8 \pm 1.5 \mathrm{a}$ & $12.7 \pm 1.1 \mathrm{a}$ & $5.764 \pm 1.044 \mathrm{a}$ \\
\hline Hydraulic conductivity $(\mathrm{cm} / \mathrm{s})$ & $0.024 \pm 0.010 \mathrm{~b}$ & $0.020 \pm 0.009 \mathrm{~b}$ & $\mathrm{a}$ \\
\hline
\end{tabular}

Note: the values in the same row followed by the same letters indicate no significant difference $(\mathrm{p} \leq 0.05)$

Table 5. Correlation analysis between peat hydro-physical variables.

\begin{tabular}{|c|c|c|c|}
\hline Variable & $\begin{array}{c}\text { Water } \\
\text { content }\end{array}$ & $\begin{array}{c}\text { Dry peat } \\
\text { weight }\end{array}$ & $\begin{array}{c}\text { Hydraulic } \\
\text { conductivity }\end{array}$ \\
\hline Bulk Density & -1.00 & 1.00 & -0.97 \\
\hline Water content & & -1.00 & 0.97 \\
\hline Dry peat weight & & & -0.97 \\
\hline
\end{tabular}

the seepage. This occurs due to changes in the structure and pore spaces of the peat [38].

Correlation analysis showed that hydraulic conductivity has high negatively related to bulk density and dry peat weight. It shows that degradation in peat results in an increase in bulk density and dry weight, which will reduce the ability of peat water movement through the peat profile. Degradation of peatlands due to peat processing and drainage activities will be followed by faster decomposition and mineralization.
This process will increase the number of micropores and reduce macropores. This change will affect the peat's ability to absorb and store water, indicated by the high fluctuation in the peat water level [39].

\section{Discussion}

In the intensive agricultural land, the farmer uses the land up to four circle times in a year. In contrast, 
farmers in the non-intensive agricultural land plant only once a year or fallowed for several years but are still to be used as agricultural land. Constraints are faced generally in the form of low crop viability due to inadequate nutrients and the presence of organic acids from the peat. Besides, they are physically constrained by large tree stumps that are still a lot left on the land surface. In the hydro-physical aspect, drained peat tends to cause water shortages during the dry season and high fire susceptibility.

The intensive agricultural land management significantly improves peat chemical characteristics for the variable of available $\mathrm{P}$, available $\mathrm{K}, \mathrm{Ca}$, and Exchangeable K. Some other elements also changed but not significantly different from the control (forested peat). The addition of wood ash can significantly improve the availability of $\mathrm{P}$. The increased content of exchangeable bases on peat agricultural land was also affected by fertilizing and adding the ash [40]. Ash is the essential input to correct $\mathrm{pH}$, fertility and suppress the toxic peat effects. A massive amount of ash is required as a soil amendment, then efficient technologies in creating and utilizing ash are needed and the alternative of the use. In Kalampangan, farmers usually produce the ash from wood waste, which is widely spread over the land surface. The ash was produced through controlled burning and done outside the peatland area. This is done to prevent uncontrolled flames from spreading to the peat's side or bottom, but this method still poses a risk of peat fire and smoke.

An alternative of the ash used has been formulated by BPPT (Agency for the Assessment and Application of Technology) researchers, known as special peatland fertilizer, as a soil conditioner that consists of a mixture of volcanic ash, potassium chloride fertilizer, and urea fertilizer. Also, the Soil Research Institute launched PUGAM-A, a granular slow-release fertilizer product. The product is applied to supply plant nutrients, reduce the adverse effects of toxic organic acids, reduce $\mathrm{P}$ leaching, and effectively suppress $\mathrm{CO}_{2}$ emissions. The fertilizer effectively reduces $\mathrm{P}$ leaching because it has a slow release property and forms positive footprint sorption on the peat that can control P leaching.

Changes in the peat layer will affect the water absorption. Naturally, peat has high water content. The difference in water content can occur apart from being influenced by the level of peat decomposition, it is also influenced by its constituent materials and chemical content [29]. On a broad scale, it will affect the water system by reducing water storage absorption, increasing surface runoff, and river discharge. Excessively drained peat coupled with the peat surface layer's burning caused a decline in the ability to store water, giving rise to a complex hydrological response. The effect can be seen with increased surface runoff accompanied by increased erosion and increased peak flows of a river stream. Another impact is subsidence occurrence due to compression/shrinkage of peat and peat oxidation above the water table [41, 42].
The change in hydraulic conductivity due to the peat's slow water movement vertically or horizontally affects the water balance [43]. The reduction in hydraulic conductivity is inversely proportional to the increase in soil bulk density. However, the impact of drained peat on the water balance in a whole hydrological unit is still challenging to be determined. One of the things that influence the determination method of peat thickness variable can not be simplified based only on the land topography [44, 45].

Water balance in the peat is much influenced by rainfall as the primary input components, evapotranspiration, and runoff. The amount of evapotranspiration is usually constant, as much as half of the annual rainfall. The rainfall, especially during the dry season, has a vital role in maintaining the water balance of peat, significantly when evapotranspiration exceeds the precipitation. During peat in watersaturated condition, water that flows in the form of runoff or base flow will go around the river or through the drainage channels. In a peatland forest with a good cover condition, the water table is found near the land surface and will fall mostly up to $60 \mathrm{~cm}$ in the dry season. Oppositely in drained peat, the water level will decrease and reach up to $200 \mathrm{~cm}$ below the land surface [46]. Drainage channels performed on peat forest will be lowering the water level, increases runoff, and decreases evapotranspiration. The declining water level depends on the depth and density of drainage channels [43].

Land-use change from forest to agriculture will discontinue the supply of organic matter from the forest cover and affect evapotranspiration as a water balance component. The presence of trees plays a role in maintaining the temperature and humidity of the peat surface, controlling the wind speed, which lowers the evaporation rate. In tropical peat swamp forests, tree root systems can suppress the runoff and, in the end, will keep the peat wet [47]. The loss of forest role exacerbated by excessive drainage will be ascertained that the water table would be far from the peat's surface during the dry season and lead to drought and fire-prone. This situation is found in the ex-mega rice project (MRP) area in Central Kalimantan Province.

Efforts to restore degraded peatland due to excessive drainage practices or conversion of the land cover can be made by repairing the existing drainage system, such as constructing the canal blocking. The construction will force water to spread over the peatland to rewet as wide as possible [48]. The biggest challenge in doing so is balancing the cultivated land's economic interests with rewetting efforts.

The concept of sustainable crop cultivation on wet and rewetted peatlands has been developed and is known as paludiculture systems [49]. Peatland utilization as agricultural land should still retain partial cover as forest vegetation with a product orientation prioritized in non-timber forest products [50]. The use of adaptive crop and indigenous tree species 
with high economic value is highly recommended, such as Jelutong species. This species has high economic potential as a producer of latex and herbal medicine $[51,52]$. This technology's application is expected to accommodate the local community's economic interests while conserving the peatlands.

\section{Conclusions}

Peat managed as agricultural land is categorized as deep peat with a thickness of more than $3 \mathrm{~m}$ and dominated by sapric type in the surface layer. The land was managed by adjusting the water level through the construction of drainage channels. Several additional inputs were used, such as lime, manure, wood ash, fertilizers, and mineral soil.

The intensive land management significantly changes the peat chemical, as indicated by increasing the $\mathrm{pH}$, phosphor, potassium, calcium, and magnesium contents. Otherwise, the management has lowered the peat hydrological function characterized by increasing water level depth, bulk density and reducing the water content and hydraulic conductivity. Hydrological peat functions on agricultural peatland should be restored by constructing appropriate canal blocking. The application of paludiculture systems should be considered as promising agricultural land management that combines adaptive crops and suitable tree species with high economic value for the community.

\section{Acknowledgments}

The research was funded by Forest Research and Development Center, Ministry of Environment and Forestry. The authors would like to acknowledge Untung Darung (Palangkaraya University) support, and Haddy Sudiana, Iskandar, Usman Sopian, Ube, and Yobi for the field assistance during the field survey.

\section{Conflict of Interest}

The authors declare no conflict of interest.

\section{References}

1. KHAKIM M.Y.N., BAMA A.A., YUSTIAN I., POERWONOA P., TSUJI T., MATSUOKA T. Peatland subsidence and vegetation cover degradation as impacts of the $2015 \mathrm{El}$ niño event revealed by Sentinel-1A SAR data. Int. J. Appl. Earth Obs. Geoinf., 84, 101953, 2020.

2. PAGE S.E., BAIRD A.J. Peatlands and global change: response and resilience. Annu. Rev. Environ. Resour., 41, 35, 2016.

3. MAKINDA J., GUNGAT L., RAO N.S.V.K., SULIS S. Compressibility Behaviour of Borneo Tropical Peat Stabilized with Lime-Sand Column. Int. J. Adv. Sci. Eng. Inf. Technol., 8 (1), 172, 2018.
4. RITUNG S., WAHYUNTO, NUGROHO K., SUKARMAN, HIKMATULLAH, SUPARTO, TAFAKRESNANTO C. Indonesia peat soil map scale 1:250,000; Indonesia Center for Agricultural Land Resources Research and Development: Bogor, Indonesia, 2011 [In Indonesian].

5. JUNEDI H., ARMANTO M.E., BERNAS S.M., IMANUDIN M.S. Changes to some physical properties due to conversion of secondary forest of peat into oil palm plantation. Sriwijaya J. Envron., 2 (3), 76, 2017.

6. NURHAMIDAH N., RUSMAN B., ISTIJONO B., HAKAM A., JUNAIDI A. Monitoring and Empirical Modelling for Organic Soil Subsidence Estimation in Sumatra. Int. J. Adv. Sci. Eng. Inf. Technol., 8 (5), 2263, 2018.

7. DOMMAIN R., COUWENBERG J., JOOSTEN H. Hydrological self-regulation of domed peatlands in South-east Asia and consequences for conservation and restoration. Mires Peat, 6 (5), 1, 2010.

8. LIMIN S.H. Peat land utilization and its problems. Proc. the National Peatland Workshop, 2006.

9. MUSARIKA S., ATHERTON C.E., GOMERSALL T., WELLS M.J., KADUK J., CUMMING A.M.J., PAGE S.E., OECHEL W.C., ZONA D. Effect of water table management and elevated $\mathrm{CO}_{2}$ on radish productivity and on $\mathrm{CH}_{4}$ and $\mathrm{CO}_{2}$ fluxes from peatlands converted to agriculture. Sci. Total Environ., 584, 665, 2017.

10. SINCLAIR A.L., GRAHAM L.L.B., PUTRA E.I., SAHARJO B.H., APPLEGATE G., GROVER S.P., COCHRANE M.A. Effects of distance from canal and degradation history on peat bulk density in a degraded tropical peatland. Sci. Total Environ., 699, 134199, 2020.

11. ITOH M., OKIMOTO Y., HIRANO T., KUSIN K. Factors affecting oxidative peat decomposition due to land use in tropical peat swamp forests in Indonesia. Sci. Total Environ., 609, 906, 2017.

12. TAUFIK M., VELDHUIZEN A.A., WÖSTEN J.H.M., LANEN H.A.J. Exploration of the importance of physical properties of Indonesian peatlands to assess critical groundwater table depths, associated drought and fire hazard. Geoderma, 347, 160, 2019.

13. TONKS A.J., APLIN P., BERIRO D.J., COOPER H., EVERS S., VANE C.H., SJOGERSTEN S. Impacts of conversion of tropical peat swamp forest to oil palm plantation on peat organic chemestry, physical properties and carbon stocks. Geoderma, 289, 36, 2017.

14. HIKMATULLAH, SUKARMAN. Physical and Chemical Properties of Cultivated Peat Soils in Four Trial Sites of ICCTF in Kalimantan and Sumatra, Indonesia. J. Trop. Soils, 19 (3), 131, 2014.

15. DOHONG A., AZIZ A.A., DARGUSCH P. A review of the drivers of tropical peatland degradation in South-East Asia. Land Use Policy, 69, 349, 2017.

16. REZANEZHAD F., PRICE J.S., QUINTON W.L., LENNARTZ B., MILOJEVIC T., CAPPELLEN P.V. Structure of peat soils and implications for water storage, flow and solute transport: A review update for geochemists. Chem. Geol., 429, 75, 2016.

17. ROSENBURGH A., ALDAY J.G., HARRIS M.P.K., ALLEN K.A., CONNOR L., BLACKBIRD S.J., EYRE G., MARRS R.H. Changes in peat chemical properties during post-fire succession on blanket bog moorland. Geoderma, 211-212, 98, 2013.

18. ARROUAYS D., SABY N.P.A, BOUKIR H., JOLIVET C., RATIÉ C., SCHRUMPF M., MERBOLD L., GIELEN B., GOGO S., DELPIERRE N., VINCENT G., KLUMPP 
K., LOUSTAU D. Soil sampling and preparation for monitoring soil carbon. Int. Agrophys., 32, 633, 2018.

19. HESSE P.R. A Textbook of Toil Chemical Analysis. John Murray: London, UK, 520, 1971

20. ESTEFAN G., SOMMER., RYAN J. Methods of Soil, Plant, and Water Analysis. International Center for Agricultural Research in the Dry Areas: Beirut, Lebanon, 243, 2013

21. BOUWER H., RICE R.C. A slug test for determining hydraulic conductivity of unconfined aquifers with completely or partially penetrating wells. Water Resour. Res., 12 (3), 423, 1976.

22. MUSTAMO P., HYVARINEN M., RONKANEN A.K., KLOVE B. Physical properties of peat soils under different land use options. Soil Use Manag., 32 (3), 400, 2016.

23. STEEL R.G.D., TORRIE J.H. Principles and Procedures of Statistics. McGraw-Hill, New York, US, 633, 1997.

24. SAS INSTITUTE. SAS/STAT 9.1 User's Guide. SAS Institute: North Caroline, US, pp. 4884, 2004.

25. SABIHAM S. Properties of Indonesian peat in relation to the chemistry of carbon emission. Proc. International Workshop on Evaluation and Sustainable Management of Soil Carbon Sequestration in Asian Countries, 205, 2010.

26. WIJEDASA L.S., SLOAN S., PAGE S.E., CLEMENTS G.R., LUPASCU M., EVANS T.A. Carbon emissions from South East Asian peatlands will increase despite emissionreduction schemes. Glob. Change Biol., 24, 4598, 2018.

27. ARMANTO M.E. Comparison of Chemical Properties of Peats under Different Land Uses in South Sumatra, Indonesia. Ecol. Eng., 20 (5), 184, 2019.

28. JENTHA. The use of ash as fertilizer by farmers in Kalampangan. Professional Skills Report. Palangkaraya University: Palangkaraya, Indonesia, 2003.

29. HUAT B.B.K., KAZEMIAN S., PRASAD A., BARGHCHI M. State of an art review of peat: General perspective. Int. J. Phys. Sci., 6 (8), 1988, 2011.

30. YULE C.M., LIM Y.Y., LIM T.Y. Recycling of phenolic compounds in Borneo's tropical peat swamp forests. Carbon Balance and Manag., 13 (3), 1, 2018.

31. LEIFELD J., KLEIN K., GALLEY C.W. Soil organic matter stoichiometry as indicator for peatland degradation. Sci. Rep, 10, 7634, 2020.

32. NELVIA. Response of Rice and Carbon Emission to Application of Ameliorant Dregs in The Peat Soil with Saturation and Unsaturation Condition. Int. J. Adv. Sci. Eng. Inf. Technol., 4 (6), 73, 2014.

33. HARPENSLAGER S.F., ELZENA E.V.D., KOX M.A.R, SMOLDERS A.J.P., ETTWIG K.F., LAMERS L.P.M. Rewetting former agricultural peatlands: Topsoil removal as aprerequisite to avoid strong nutrient and greenhouse gas emissions. Ecol, Eng., 84, 159, 2015.

34. LAMERS L.P.M., VILE M.A., GROOTJANS A.P., ACREMAN M.C., DIGGELEN R., EVANS M.G., RICHARDSON C.J., ROCHEFORT L., KOOIJMAN A.M., ROELOFS J.G.M., SMOLDERS A.J.P. Ecological restoration of rich fens in Europe and North America: from trial and error to an evidence-based approach. Biol. Rev., 90, 182, 2015.

35. SEPTIYANA, SUTANDI A., INDRIYATI L.T. Effectivity of soil amelioration on peat soil and rice productivity. J. Trop. Soils, 22 (1), 11, 2017.

36. SURATMAN, WIDIATMAKA, PRAMUDYA B., PURWANTO M.Y.J, AGUS F. Variation of biophysical characteristics of peatland under different land cover types in Kampar Peninsula, Riau Province. Jurnal Tanah dan Iklim, 43 (2), 97, 2019.

37. HOLIDI, ARMANTO M.E., DAMIRI N., PUTRANTO D.W.A. Characteristics of Selected Peatland Uses and Soil Moisture Based on TVDI. Ecol. Eng, 20 (4), 194, 2019.

38. RAHGOZAR M.A., SABERIAN M. Physical and chemical properties of two Iranian peat types. Mires Peat, 16 (7), 1, 2015.

39. ZARZYCKI J., SKOWERA B., ZAJĄC E. Microclimate and Water Conditions of an Extracted and Natural Raised Bog. Ecol. Eng., 21 (7), 115, 2020.

40. OTS K., TILK M., AGURAIJUJA K. The effect of oil shale ash and mixtures of wood ash and oil shale ash on the above- and belowground biomass formation of Silver birch and Scots pine seedlings on a cutaway peatland. Ecol. Eng., 108, 296, 2017.

41. BADER C., MÜLLER M., SCHULIN R., LEIFELD J. Peat decomposability in managed organic soils in relation to land use, organic matter composition and temperature. Biogeosciences, 15, 703, 2018.

42. LEIFELD J., MUELLER M., FUHRER J. Peatland subsidence and carbon loss from drained temperate fens. Soil Use Manag., 27, 170, 2011.

43. SARKKOLA S., NIEMINEN M., AHTI E. Role of tree stand evapotranspiration in maintaining satisfactory drainage conditions in drained peatlands. Can. J. For. Res., 40, 1485, 2010.

44. WHITFIELD, H. HILAIRE A.S., KAMP G. Improving hydrological prediction in peatlands. Can. Water Resour. J., 34 (4), 467, 2009.

45. ZUHDI M., ARMANTO M.E., SETIABUDIDAYA D., NGUDIANTORO, SUNGKONO. Exploring Peat Thickness Variability Using VLF Method. Ecol. Eng., 20 (5), 142, 2019.

46. RAIS D.S. Peatland hydrology and its role in tropical peatland sustainability. Proc. Symposium on Ecohydrology, 2011.

47. KURNIANTO S., "The Eco-hydrology of Tropical Peatlands Associated with Land Cover Changes. Ph.D. Thesis, Oregon State University, Corvallis, US, 2017.

48. RITZEMA H., LIMIN S., KUSIN K., JAUHIAINEN, J. WÖSTEN H. Canal blocking strategies for hydrological restoration of degraded tropical peatlands in Central Kalimantan, Indonesia. CATENA, 114, 11, 2014.

49. TAN Z.D., LUPASCU M., WIJEDASA L.S. Paludiculture as a sustainable land use alternative for tropical peatlands: A review. Sci. Total Environ., 753, 142111, 2021.

50. TATA H.L., SUSMIANTO A. Prospect of paludiculture: Indonesia Peat Ecosystem. FORDA Press: Bogor, Indonesia, 2016.

51. INDRAYANTI L., ROTINSULU J.M., YANARITA Y., SOSILAWATY S. Peat Swamp Forest: Management and Development of Indigenous Species to Support Economic Local People at Periphery Foret (Case Study in Central Borneo, Indonesia). Ecol. Eng., 20 (4), 76, 2019.

52. TATA H.L., VAN NOORDWIJK M., JASNARI, WIDAYATI A. Domestication of Dyera polyphylla (Miq.) Steenis in peatland agroforestry systems in Jambi, Indonesia. Agrofor. Syst., 90, 617, 2016. 